\title{
МАЛЬЦЕВА ОЛЬГА,
}

кандидат філософських наук, доиент кафедри соиіології та соичіальної роботи, Приазовський державний технічний університет, м. Маріуполь

\section{ФЕНОМЕН КАРНАВАЛІЗАЦІї СПОРТУ В ПОСТМОДЕРНОМУ СУСПІЛЬСТВІ}

\begin{abstract}
У статті досліджується феномен карнавалізації спорту в постмодерному суспільстві, виявляються історичні витоки, причини, передумови, наслідки постмодерної трансформації спорту як соціального інституту, перетворення його на комерціалізоване видовище, індустрію, шоу-бізнес, розважальну практику дозвілля. Простежено взаємне проникнення сміхової стихії у спорт та спорту в карнавалізований соціокультурний простір.
\end{abstract}

Ключові слова: сміх; спорт; карнавалізація спорту; постмодерний спорт; соціальні функції сміху.

Постановка проблеми. Суцільна карнавалізація, що охопила соціокультурний простір сьогодення, не оминула своєю увагою спорт, підкресливши й без того складний і суперечливий характер його розвитку. Спорт тепер нерозривно пов'язаний з усіма сферами суспільного життя (економічною, політичною, культурною тощо). Як зазначає М. Мосс, спорт став "всеосяжним соціальним явищем" [1, с. 242-263]. Ця тенденція особливо помітно проявилася на поч. XX ст., що послужило приводом для глибокого соціально-фрілософського та психологічного аналізу еволюції спорту. На межі XX-XXI ст. карнавалізація і спорт як два тотальних феномени постмодерного суспільства взаємно поглинули одне одного, породивши феномен карнавалізованого спорту. Поняття "карнавалізація спорту" першим застосував Умберто Еко, коротко й змістовно визначивши природу цього гібридного утворення. "Карнавалізується спорт. Як? Спорт - гра за визначенням. Чи можна карнавалізувати гру? З'ясовується, можна - перетворивши гру 3 рідкісного задоволення (колись показували раз на тиждень матч і раз у чотири роки - Олімпіаду) на повсякденне видовище. При подібній карнавалізації спорт стає вже не видовищем - індустрією" [2, с. 146]. Отже, стан сучасного спорту принаймні отримав визначення. Проте виникає потреба в більш детальному дослідженні історичних витоків, ознак карнавальності, що вони просякнули постмодерну спортивну індустрію; виявленні причин, соціокультурних передумов, за яких активізувалася сміхова стихія, котра накрила своєю хвилею спорт, а карнавалізований спорт вихлюпнувся в повсякденність. Уже зараз зрозуміло, що наслідки цього зустрічного руху можуть бути непередбачуваними. Через це постає проблема майбутніх перспектив карнавалізованого спорту щодо його здатності виконувати свою гуманістичну місію, сприяти фрізичному, психічному та соціальному здоров'ю людини, розширювати горизонти або визначати межі її досконалості, гармонізувати ї̈ біосоціокультурну природу.

Карнавалізований спорт з усією очевидністю демонструє здатність долати стереотипні уявлення про цей вид соціальної активності як неутилітарний. Окрім того, світоглядні настанови, що він їх стверджує, створюють нові соціальні контексти, породжуючи "спортивне світовідчуття епохи", "спортивний сенс життя", а також "спортивно-святкове відчуття буття" (Х. Ортега-і-Гассет). Утім, будь-який карнавал, у тому числі спортивний, $€$ явищем межовим, він завжди позначає певний рубіж. Зазвичай веселощі, вибухи сміху, торжество несерйозності, інверсійний характер дій святкового порубіжжя мають визначене спрямування - подальше встановлення порушеного порядку й соціальної ритміки.

Очевидно, класичні ідеали спорту, що здебільшого загублені у вирі карнавалізованого розгулу, потребують відновлення, але навряд чи "після карнавалу" вони будуть відтворені в незмінному вигляді. Прояснення причин активізації соціального несвідомого у формі сміхової стихії щодо визначення ролі спорту в житті людини та суспільства $є$ актуальним завданням, вирішення якого може наблизити й до розуміння алгоритму дії сміхових настроїв у перехідні часи, у кризових станах розвитку людства. Адже спорт - це лише одна з ланок прояву карнавальної гри сьогодення, яка повсюдно змішує смисли, ламає звичні правила, випробовує на життєздатність, здавалося б, непорушні цінності людського буття з метою утворення нових смисложиттєвих орієнтацій та ціннісних ієрархій.

Аналіз останніх досліджень і публікацій. В основу поданої наукової розвідки покладено матеріали попередніх досліджень зарубіжних та вітчизняних авторів, які можна представити декількома тематичними локусами: проблеми історії, філософії, психології, соціології спорту (Х. Ортега-і-Гассет, П. де Кубертен, П. Бурдьє, Й. Хейзинга, М. Вебер, М. Мосс, Р. Барт, У. Еко, У. Морган, А. Гуттман, Т. Алкемейєр, С. Абдулкарімов, М. Ібрагімов, М. Сараф, В. Столяров, В. Хамітов та ін.); ідеологічне підґрунтя і стан суспільства в умовах постмодерну (Ж. Бодрійяр, Ж. Дерріда, М. Фуко, Ж. Липовецький тощо); семіотична теорія карнавалу і карнавалізації (М. Бахтін, С. Аверинцев, Ю. Лотман та ін.); соціокультурний простір як системне утворення; циклічний та варіативний характер його розвитку (Ф. Ніцше, Г. Дебор, К. Юнг, Г. Маркузе, Е. Канетті, П. Берк, К. Леві-Стросс, К. Леві-Брюль, О. Лосєв, В'яч. Іванов, Н. Еліас, І. Стергенс, І. Пригожин); сміх як біосоціокультурний феномен і чинник соціокультурних зрушень (Дж. Джеймісон, І. Хассан, Т. Адорно, М. Хрєнов, А. Козинцев та ін.).

Виокремлення області дослідження. Карнавалізований спорт є яскравим утіленням втручання сміху як агента соціальних змін у процес формування нових культурних ландшафтів, світоглядних парадигм, стандартів способу життя. Соціальні функції сміху щодо деформації й руйнації одних цінностей і смислів та утво- 
рення інших у контексті постмодерної трансформації спорту є малодослідженими. Особливий інтерес викликає здатність сміху через його амбівалентність як наближати людину до природи як джерела натхнення, повертати їй свіжість сприйняття світу, так і віддаляти, дистанціювати від неї. Спорт, що поринув у карнавальний спосіб існування, все частіше продукує симулякри, пусті знаки, які втрачаються в потоці інших "срейків" симулякризованого простору надмірностей. За таких обставин виникає питання про можливість збереження найкращих рис спорту в його класичному (не карнавалізованому) вимірі та призначення в цьому процесі сміху.

Метою статті $\epsilon$ виявлення ролі сміху як чинника соціальних змін щодо карнавалізації спорту в постмодерному суспільстві. Для досягнення мети виконано проміжні завдання: по-перше, досліджено історичний взаємозв'язок спорту і сміху; соціокультурні передумови, що створили поживний ґрунт для карнавалізації спорту; по-друге, проаналізовано дію сміхової стихії як маркера перехідних часів, а також функцій сміху в інституалізації та демонтажі попередніх історичних форм спорту й соціокультурних цінностей, створенні унікального постмодерного симбіозу - карнавалізованого спорту; потретє, визначено світоглядні настанови, що виникають під впливом втручання сміху в спортивне життя, можливі негативні та позитивні наслідки карнавального режиму існування спорту.

Методологію дослідження склали системний, структурно-функціональний, порівняльний аналіз, метод історичної реконструкції, окремі прийоми соціологічних та психологічних досліджень, елементи синергетичної парадигми тощо.

Виклад основного матеріалу. Людина як біосоціокультурна істота вписана в природне, соціальне, культурне життя, кожне з яких має циклічний характер розвитку. За всіх часів людина потребувала гармонізації та синхронізації природних та соціокультурних ритмів, адекватного синтезу всіх своїх іпостасей задля відчуття повноти буття, усвідомлення смислу та мети власного існування. Перехідні етапи, що відділяють цикл від циклу, індивід і суспільство переживають як кризові, коли відбувається відмирання одних настанов, цінностей, ідеалів та формуються нові. Символіка Смерті-Відродження, прив'язка до стародавніх аграрних культів, ритуалів, обрядів збережена й у генетичній пам'яті спорту з його видовищністю, ігровим складником, сміховими практиками. Інобуття гри, її незвичайність, неповсякденність, святковий, піднесений настрій включали в її орбіту такі культурні феномени, як сміх, сміхову поведінку/антиповедінку, ритуальне переодягання, маску, карнавал, карнавалізацію.

Спроби визначити онтологічне коріння спорту неодмінно призводять до зіткнення різних концепцій, котрі, у всякому разі, відбивають динамічну природу цього феномену, його "чутливість" до будь-яких еволюційних зрушень. Специфрікою спорту як соціального інституту на всіх етапах становлення були не стільки "...усталені форми його організації та регулювання, скільки спосіб уведення індивіда в соціум" [3, с. 1-4]. Сучасний стан карнавалізації спорту є закономірним етапом його попереднього розвитку. Розглядати постмодерний спорт у відриві від історично більш ранніх його форм недоречно. Не претендуючи на докладну реконструкцію, відзначимо лише ключові контрапункти становлення спорту, тим більше, що досвід створення таких оглядів під різними кутами зору вже започатковано. Дослідники історії, фрілософрії, соціології, психології спорту та ін. у цьому намаганні схильні до "транзитних" формулювань, які дають експрес-пояснення загально- го напрямку трансформацій спорту як руху "від ритуалу до рекорду", "від священного до секулярного", "від духу до тіла" (А. Гуттман), "від гри до агресії" (С. Абдулкарімов), "від гри до карнавалу" (У. Еко) тощо. У цій частині досліду відстежимо зв'язок спорту як ритуалу, гри, видовища, змагання зі сміхом і сміховими практиками, визначимо характер і механізм цієї взаємодії.

Вочевидь, жага до видовищ виникла чи не одночасно 3 появою самого homo sapiens. Первісний спорт (звісно, що так його можна називати лишень умовно, бо тоді ще не існувало визначення цього виду фізичної діяльності) був своєрідною моделлю задля випробовування екстремальніших життєвих ситуацій - мисливства, бою, стихії, спасіння від небезпеки. Він мав, окрім суто утилітарних цілей, побічний ефект - радісну ейфорію від відчуття власних можливостей. Приміром, X. Ортега-і-Гассет джерело виникнення спорту вбачає у вільній грі життєвих сил, що породжують спонтанне, надмірне, неекономічне зусилля [4, с. 137-152]. На ігровій, непрактичній природі спорту наполягає іЙ. Хейзинга [5, с. 319328]. Саме відчуття наявності того самого надлишку сил, що перебільшує необхідні для простого виживання, породжують додаткову фізичну активність, яка супроводжується дикунським сміхом, емоцією радіння від усвідомлення власного потенціалу.

За твердженням К. Дієма, так чи інакше "...усі фрізичні вправи від самого початку були пов'язані з культом" [6, с. 1-3]. Цієї ж думки дотримується етнограф, дослідник культури південно-східних апачів-хікарілья (індіанці Великих рівнин) С. Калін, який звертає увагу на веселі розваги з відбиванням м'яча, потішні бої, ігри, наслідувальний спорт у дітей цього індіанського племені. Дитячі веселощі не були самостійним явищем, а лише повторювали обрядові дії дорослих, які відбувалися у визначену пору року, у рамках свят і релігійних ритуалів, що були покликані задовольнити богів, забезпечити родючість землі, навести дощ, зачати або подовжити життя, вигнати злих духів, зцілити від хвороби. У таких ритуалах родючості фізичні ігри, сміхові практики здійснювалися з урахуванням циклів Сонця та Місяця, які символізували, відповідно, чоловіче та жіноче начала й відбивали "дихотомічне сприйняття природного порядку" (К. Леві-Стросс). Центральними фігурами цього дійства були молоді люди, що статево дозріли, але ще не взяли шлюб. Включення у гру з м'ячем як солярним символом мало забезпечити продовження роду. Свято зазвичай закінчувалося співами пісень, веселими танцями, сміховими ігрищами. Дослідниця К. Ює-Керкдаль стверджує, що в лоні архаїчних ритуальних, культових змагань виникали й секулярні спортивні практики, смисл яких полягав у них самих.

Безумовно, найбільш масштабним, розгорнутим та видовищним поєднанням ритуальних фізичних вправ зі служінням богам $є$ давньогрецькі Олімпійські ігри. Більшість дослідників історії спорту, незважаючи на те, що Олімпійські ігри Стародавньої Греції, по суті, були "обрядовим жертвопринесенням богам здоров'я людей", саме в них убачають фундамент сучасного спортивного руху [7, с. 100].

Для греків Олімпійські, Істмійські, Немейські, Афрінські та ін. ігри являли собою священні свята, невід'ємну складову релігійного життя. Це було справжнє священнодійство, бо ігри проводилися в сакральному місці, у спеціально призначені для того дні. Олімпійські події від початку до кінця - це присвята богам, поклоніння та служіння їм, що позначилося на структурі ігор як постановочних дійств. О. Лосєв стверджував, що "для античності космос сприймався як театральна вистава, у якій люди виконують свої ролі, хоча п'єса вибудовувалася 
самою долею" [8, с. 164]. Атлети, котрі змагалися на Олімпійських іграх, безперечно, мали певні особисті амбіції щодо визнання, примноження власного престижу. Утім, головним вони вважали не ігри на першість, а "присутність", себто участь у сакральній виставі, у якій ними виконувалась відведена їм роль і де самі боги обирали переможця, тим самим підтверджуючи свою прихильність до цих ритуальних дій.

Можна погодитися з В. Косяк: "Найдревніші релігії це "релігії тіла", у яких духовне ще, можливо, не почало усвідомлюватися в його відносній автономності, оскільки воно ще, очевидно, не сформулювалось і онтологічно" [9, с. 140]. У греків фрізична краса і сила сприймалися як дар богів, тому вони дарували (у значенні "віддарювали" або, як сказав би Ж. Бодрійяр, здійснювали символічний обмін), приносили їм у якості жертви свою фрізичну досконалість. Олімпійські ігри здійснювалися на честь Зевса, Істмійські присвячувалися Посейдону, у Дельфах і Немеї бігуни й борці вклонялися Аполлону.

В основі Олімпійського культу, як і в більшості архаїчних ритуалів наявна символіка родючості. Олімпія це місце, присвячене Геї - богині землі. За свідченням греків, ігри тут заснував Геракл, який лише згодом був "розжалуваний" у герої, а за мінойських часів був богом родючості. Змагання відбувалися власне над могилою героя Пелопса, який начебто під час ігор відроджувався через приношення чергового юнака в жертву. Поразка в атлетичному змаганні була символічною заміною ритуального жертвопринесення. Отже, будь-які атлетичні зусилля були спрямовані на переконання бога повстати від смерті та знов з'явитися у вигляді ростка, що виходить із темної могили на сонячне світло.

Олімпійські ігри завершував урочистий бенкет, де радощі, піднесення й веселощі були знаком віддяки богам за їхню "чуйність". На бенкеті вшановували переможців, яких нагороджували дарами богів - вінками з оливи, маслин, лавру, сосни, селери, що вважалася поховальною рослиною й, вочевидь, була знаком прийняття богами жертви. "Коронацію" здійснювали хлопці, у яких обоє з батьків були живі (що символізувало ритуальне життєствердження). Загальна радість і веселий сміх виражали задоволення від того, що завдяки відтворенню олімпіоніками міфічних дій богів та героїв забезпечувалася космічна рівновага, відновлювався укладений богами й героями спосіб життя.

На думку П. Фрейсіне, змагальність ("агон") у давніх греків мала за формою артистичне вираження, оскільки богів можна було задовольняти, приносячи їм у дар музику, танець, поезію, драматичну виставу або атлетичне змагання [10, с. 27]. Проте давньогрецький олімпійський спорт не був різновидом мистецтв, він становив собою героїчне жертвопринесення, у якому були задіяні не лише атлети, але й тисячі учасників ритуалу, що збиралися у священному сосновому гаю. Це була насичена урочистою напругою очікувань ойкумена. Емпатичне переживання відвідувачами Олімпійських ігор настроїв атлетів, їхній екстатичний, святковий стан призводив до втрати людиною свого "Я" і занурення в колективне переживання виходу "поза межі" культурного світу. В'яч. Іванов відзначає, що в такому "тимчасовому скасуванні "Я"' $€$ схожість 3 діонісійськими обрядами, коли у сміху та веселощах "розмиваються останні грані індивідуального" [11, с. 167]. Усезагальне радісне піднесення слугувало медіації між "Я" і "Ми", між надприродним світом та світом соціуму, культури, між теперішнім та прийдешнім. Екстаз від відтворення космічної рівноваги дозволяв архаїчній людині долати свою обмеженість, виходити поза час-простір і звідти спостерігати грядуще.
Святкові дні Олімпіади ставали періодом, коли час зупинявся й завдяки обрядовим діям греки поверталися в "золотий вік", тобто в добу міфу, коли предки створювали позбавлений суперечностей космос. 3 моменту оголошення про настання священного місяця ігор припинялися всі війни. Люди потрапляли у своєрідну утопію, під час якої нищилися негативні емоції, панування радощів і сміху сприяло переживанню екстатичного єднання з надприродним началом, священного катарсису, появі перспектив подальшої рівноваги та стабільності в суспільстві, відкриттю нових патернів розвитку. Показово, що, окрім змагань атлетів, тут підписували торговельні угоди, проходили публічні виступи поетів, музикантів, діяли виставки робіт скульпторів і художників, а також оголошувалися нові закони, договори, обговорювалися важливі документи. Роль сміху як "посередницького" засобу добре ілюструє той факт, що покровителем атлетів Давньої Греції був олімпійський бог Гермес, який $є$ одним із міфологічних трикстерів, архетипових образів сміхової стихії й культурного героя водночас, "проміжною ланкою" між надприродним i земним світами, між хаосом і порядком, між природою та культурою.

Завдяки "дієвості" ритуального святкового дійства у свідомості громадян Давньої Греції стверджувалися ідеали калокагатії, тобто єдності внутрішньої та зовнішньої краси як утілення в людині божественного. Як помітив М. Мосс, "в жертві завжди є щось божественне, що вивільнюється в момент принесення в жертву" [12, с. 85]. Отже, давні греки намагалися завдяки вольовому напруженню й підпорядкуванню тіла сягнути вершин духу, божественного стану.

Ці ідеали виходили за межі власне ритуалу в повсякденній практиці, оскільки під впливом атлетичних подвигів олімпіоніків у суспільстві поширювалися заняття гімнастикою як цілком секулярне явище. Це не означає, що в щоденних заняттях фізичними вправами вихолощувався їхній релігійний зміст, просто вони вже не були частиною ритуалу, а здійснювалися на виконання соціальної норми - культу здорового, сильного, красивого тіла. За твердженням Г. Ріссе, "... грецький спорт базується не на якихось матеріально-економічних підставах, а просто на радісному сприйнятті красивого тіла" [13, с. 56-67]

У Давньому Римі панували дещо інші настрої з притаманним їм духом випробовувань, затятої боротьби та жорстоких змагань. Усі види фрізичної активності тут дедалі більше секуляризувалися. Відтворити повноцінні Олімпійські ігри за грецьким зразком римлянам не вдалося. Вони не цікавилися бігом або метанням диску. "Грецький принцип тілесної гармонії і турбота про тілесну красу й витонченість уважалися ознакою жіночної зніженості" [14, с. 179]. Ті, хто хоч якось видавав у собі тягу до грецьких стандартів, нещадно висміювалися. На цьому етапі через осміяння руйнувалися старі спортивні ідеали та запроваджувалися інші. Римські джерела зберегли відомості про випадок, коли сміховій обструкції громадяни піддали навіть Сципіона Африканського, який переміг Ганнібала в Третій Пунічній війні, позаяк той з'явився в гімнасії одягненим на грецький манер [14, с. 179]. Тепер ідеалом стає м'язисте тіло, що може слугувати зброєю на війні, брутальність набуває особливої цінності. Звичайні та кулачні бої, панкратіон стверджуються як головні спортивні події в римлян. Грандіозні вистави мали успіх, оскільки на сцені з'являлися поперемінно загони кінноти і піхоти, у святкову дію включалася хода полонених, виступи рідкісних тварин, згодом - страта перших християн. Популярними були показові змагання грецьких атлетів, сольні 
пантоміми на різноманітні міфологічні сюжети під музику і співи хору, комедії, циркові трюки, різноманітні постановки, але найбільше цінувалися бої гладіаторів у амфрітеатрах.

У шаленому запалі жорстокості глядачі майже й не згадували про те, що гладіаторські бої походили від традиції погребальних ігрищ етрусків та римлян, в останніх - на могилі отця Марка та Децима Брута. Закладена в них символіка подолання смерті й продовження життя через нащадків і майбутні покоління втрачалася. Криваві гладіаторські бійки відбувалися під гаслом "Хліба та видовищ!" і супроводжувалися розлитим по рядах римського Колізею глузливим сміхом. Це був сміх зверхності, домінування, презирства щодо переможених. Як слушно відзначає Ф. Ніцше, "сучасна людина навіть не може уявити собі, до якого ступеня жорстокість складала величну радість давньої людини, примішуючись як інгредієнт майже до кожних веселощів" [15, с. 447]. У цих пихатих розкатах сміху стверджувалися давньоримські ідеали сили, нестримного гедонізму, переваги тіла над духом. Колективний сміх висвячував жорстокість як соціальну норму. За твердженням Н. Еліаса, "жорстокість не була приводом для виключення людини із життя суспільства. Радість від спостереження страждань та смерті інших була величезною і мала суспільно визнаний характер. У певній мірі побудова суспільства навіть стимулювала рух у цьому напрямку, перетворюючи таку поведінку в необхідну і доцільну" [16, с. 274]. Секулярність та інші характерні риси римського спорту дозволили А. Гуттману дійти висновку, що сучасний спорт радше близький до нього, аніж до грецького зразка [17, с. 15-55].

Середньовічний тип відношення людини до світу, смисл її буття формуються на підставі феодальної власності, станової замкненості, духовного панування християнства, переваги духовного цілого, вічного над індивідуальним прийдешнім. Усі ідеали, що надихали античність, - радість земного буття, чуттєве сприйняття реального світу, уявлення про людину у всій її міцності, славі як прекрасного створіння, витіснені відчуттям гріховності їі єства, засудженням усіх веселощів як богохульних. Усе життя середньовічної людини було чітко регламентоване та проходило між літургією і карнавалом. Вектор змін у спорті цього періоду можна визначити як рух "від атлета до аскета". Окрім того, варто зауважити, що середньовіччя стало історичним перехрестям спорту і карнавалу. П. Бурдьє свого часу поставив перед дослідниками завдання "визначити, з якого моменту чи, радше, за яких соціальних умов дійсно стало можливим говорити про спорт", "як ця галузь із своєю особливою логікою стала місцем абсолютно особливих соціальних практик", у котрих виникли перші "закони спорту", "реєстрація [recording] та прославлення відповідних досягнень, створення поля та його езотеричних значень" [18, с. 341-346].

Слово "спорт" походить від англійського "sport", що відомо 3 XV ст. Воно $€$ скороченням від "disport", що означало "розважальна та розслаблювальна діяльність, яка приносить задоволення". Слово було відомо ще раніше - з 1300 р. У XIV ст. воно набуло додаткового значення - "час для гри, флірту, задоволення від цих дій". Це слово, за Х. Ортега-і-Гассетом, було запроваджене моряками Провансу, які ним позначали час, коли не треба виходити в море й можна розважитися в порту [4, с. 140-151]. Слово "disport" утворене від давньофранцузького "desport", "deport", що, своєю чергою, походить від латинського "de porto" і значить "життя в порту". Дослівно "deport" перекладається як "дозвілля, насолода, радість, утіха, перевага". На противагу важкій, вимушеній праці моряків на морі, життя в порту ("de porto"), хоча й було сповнене напруги, але зовсім іншої - невимушеної: як правило, це були фізичні вправи. Тому "de porto" й стало означати "спорт". Сьогодні слово "sport" зберігає початкове значення винятково в жартівливому смислі. Уже з 20-х рр. XV ст. воно набуває сучасного значення, а саме: "гра, що потребує фізичних зусиль".

Карнавал також цілком середньовічний феномен, відомий з IX-X ст., але найяскравіших форм він набув у період Пізнього Середньовіччя. Народне святкове гуляння-маскарад із веселощами, іграми, розвагами й забавами починалося навесні, у день Богоявлення, та закінчувалося напередодні Великого посту - у середу, день поминання померлих. Слово "карнавал" походить від французького "carnival", італійського "carnevale", від латинського "carrus navalis" - "візок-корабель", у народній етимології - з пізньолатинської "carne" - "м'ясо", "vale" - "прощавай". Карнавальна обрядова традиція продовжувала "народну сміхову творчість", генетично пов'язану зі стародавніми святами аграрного типу. У жорстко регламентованому та ієрархізованому феодальному суспільстві ритуальний сміх переходить на неофіційне положення, але все одно виривається назовні у вигляді карнавалу. Середньовічна людина ще дуже близька до природи. Соціокультурний світ із його соціально-класовими утисками, безмежною владою церкви видався справжнім випробовуванням для її чуттєво-емоційного світосприйняття навколишньої дійсності. Карнавал був "народним тілом", яке прагнуло до лона природи, це був орган "відтворення людиною своєї свободи" (В. Назінцев). У карнавальному середовищі створювалася атмосфера свободи, рівності, скасовувалася соціальна ієрархія. Карнавал просякнутий традиційними уявленнями про циклічність часу, про вічне оновлення життя після смерті, родючість, жертвоприношення й еротику та подібні аграрні культи й новорічні свята середземноморських народів. Карнавальні інверсії, увінчання / розвінчання, бінарні опозиції (М. Бахтін) торкнулися й середньовічних спортсменів.

Карнавал є символом мерехтіння буття: усе начебто $є$ і немає, то щось виникає, то десь губиться. Основні модуси цього дивного стану розігруються на ярмарку, у цирку, на центральному майданчику міста: акробатами - перегортання, жонглерами - метушіння, довільне зникнення та повернення речей - ілюзіоністами.

Але найбільш символічною фігурою середньовічного свята є лицар, бо його справа - здійснювати подвиг. Демонстрація безстрашшя була необхідною складовою карнавалу, іноді воно доходило до божевілля, кривавої розправи над супротивником. Випробовування власних сил для середньовічних спортсменів було можливістю перевірити свою вдачу, переконатися в покровительстві вищих сил. Подвиг - це спроба взяти Бога приступом, поставити його перед фактом, - ось я з'явився перед тобою, а тепер роби зі мною, що забажаєш. Той, хто перемагає, отримує Божу благодать і сам стає провідником Божої волі.

В умовах жорсткої феодальної ієрархії середньовічний спорт був статусним заняттям. Хоча в містах виступали акробати, стрибуни, жонглери, линвоходці, ходулісти, а в селищах проводилися кулачні бої, але ці заняття не мали ніякої атлетичної спеціалізації. Лицарські турніри, навпаки, регламентували писані норми, про що свідчить Манесський кодекс. Узяти участь у лицарському турнірі або тенісному змаганні міг тільки заможний феодал. Через визначене місце лицаря в соціальній структурі феодального суспільства по відно- 
шенню до нього висувалися вимоги, за якими він мав жити: передусім, служити Богові, сеньйору, приклонятися перед Прекрасною дамою, у чому проглядалося відлуння поклоніння Діві Марії. Внутрішня стриманість та смирення "перед земним уділом" цілком могли поєднуватися в лицаря із зовнішньою відкритою агресивністю, адже війна в часи середньовіччя - сакральна, освячена церквою дія, що потребує певних бойових кондицій від її учасників.

Турніри проводилися з ініціативи призвідників "не 3 лихим умислом, але в усій любові та дружбі, аби принести задоволення (захиснику) та розважити прекрасних дам". Приводом для змагання могли стати церковні свята, дні весіль принців крові, дні народження спадкоємців або поховання королів, ярмарки тощо. Нестриманість емоцій, які виплескувались на святковій площі в ході лицарських боїв, сприяла регуляції природних інстинктів людей. Відчайдушні бої, як правило, були складовою карнавалів, народних ігрищ, святкових змагань, у яких підтримувався або дух войовничості, або колективна солідарність - "перед смертю всі рівні".

Змагальні дії розгорталися перед очима завмерлої юрби на спеціально вибудованому майданчику, часто серед ярмаркових яток. Ті, що спостерігали за протистояннями з трибуни, були колишніми супротивниками лицаря, його васалами, дітьми, дружиною чи Прекрасною дамою. Цілком задіяні у вирій подій вони не були байдужими роззявами. Лицарська звитяга мала бути справою честі й гідності, вона сприймалася як перемога на полях військових зіткнень, а поразка - як смерть. Пролиття крові в календарні свята асоціювалося з благополуччям громади, а на поминальних чи весільних обрядах було даниною пам'яті та відданості предкам, символізувало життєздатність лицаря та його родини. Чи варто говорити про те, що святкова площа зустрічала переможця радісно, зі сміхом захоплення мужністю, стійкістю перед випробуваннями, бо фізична міць лицаря уособлювала в конкретній людині гарантію загальної безпеки, захищеності.

Однак амбівалентність сміху давалася взнаки: одразу ж після змагання в жартівливій формі люди розігрували сцени бою, спеціально навчені мавпи в латах пародіювали лицарські турніри, розвіюючи страх перед священним і авторитарним. Після завершення середньовічні спортивні змагання потопали в невгамовній сміховій стихії, гомоні ярмаркового натовпу, лицарських бенкетах, танцях, святкових веселощах. Сміхова розрада, що увінчувала лицарські турніри, тільки підкреслювала серйозність і нормативність офіційних вимог, насамперед, середньовічних феодальних настанов служіння Богові, сеньйору й дамі, а також лицарських ідеалів - воїнської доблесті, слави, турботи про честь.

Пізнє Середньовіччя $€$ останнім періодом, коли в спортивних змаганнях явно простежувався зв'язок із релігійними підтекстами. Незважаючи на близькість спорту до народних свят з їхніми танцями, піснями, сміхом, намаганням зламати всі умовності та ієрархії, висміюванням лицарських турнірів, вони сприймалися як певна форма богослужіння, як поклоніння джерелу, завдяки якому все це ставало можливим. Надалі спорт буде все більш секуляризованим. Це не означає, що спортсмени як суб'єкти цього виду соціальної активності будуть відмовлятися від релігії чи релігійних настанов, ідеться про поступову відмову від матриці ритуалу, яка була в ньому закладена ще за часів архаїки, або існування лишень її театралізованих, комерціалізованих зовнішніх форм. Між спортсменом та спостерігачами змагань утрачається спільна "містична участь" (партиципація, співучасть) (Л. Леві-Брюль), їх тепер розділяє певний рубіж, між ними встановлюються рампи, прилавки тощо.

Не дивно, що символічною фігурою, яка пов'язує епоху Середньовіччя та Новий час, $є$ Дон Кіхот, літературний герой роману поч. XVII ст. "Хитромудрий ідальго Дон Кіхот із Ламанчі" іспанського письменника Мігеля де Сервантеса Сааведра. Дон Кіхот є знаковим образом, архетипом європейської культури. Вигаданий персонаж став утіленням цілої епохи, виразником загальнолюдських цінностей та ідеалів. На перший погляд, немічний, старий, худорлявий Дон Кіхот є пародією на героїчного лицаря, учасника лицарських турнірів. Його вчинки комічні, дії незграбні й беззмістовні. Трансформований архетип героя в образі Дон Кіхота перетворюється на трикстера, чию абсурдність підсилює "вірний зброєносець" Санчо Панса. "Дон Кіхот не просто лицар, це герой-воїн, герой-спаситель, герой-наставник, герой-мудрець, герой-закоханий, герой-поет, геройблазень, герой-жертва" [19, с. 112-114]. Функції, що їх виконує Дон Кіхот, контамінуються, претендуючи на роль культурного героя, він повсякчас поводиться як трикстер - архетип сміхової стихії [20, с. 213-234]. Мігель де Унамуно називає його "втіленням цінностей християнської культури", комічним героєм, який намагається битися з велетнями, чудовиськами та драконами, яких уже немає. Змінюється епоха, змінюється образ суперника. Дон Кіхот, що змагається з вітряками, видається смішним, його пафосна спроба протистояти злу цивілізації, порокам, що вона їх породила, має безперспективний вигляд і віщує кардинальні зміни.

Раньомодерний час 3 його раціоналізмом, меркантилізмом і практицизмом перетворив спорт на різновид комерційного дозвілля, веселої розваги та підігрів споживацьке ставлення до нього. Тепер виробники спортивних видовищ та їх споживачі, спортсмени і глядачі розділені назавжди між собою. Після революції 1640 р. в Англії вперше стверджується буржуазне ставлення до спорту як чинника суспільного прогресу у Старому світі. Спорт поступово вписується у фінансово-економічний, політичний і культурний виміри суспільства. Наприклад, із кінця XVII ст. в Англії за підтримки королівського двору активно розвивалися кінні змагання, що за характером організації нагадували свято й водночас забезпечували економічну стабільність цілого ряду міст та містечок, перетворювалися на справжню індустрію "з тисячами працівників та інвестиціями, які сягали сотень тисяч фунтів" [21, с. 265]. Знаковою подією стає започаткована в Парижі практика поєднання шопінгу як розваги зі споживацьким ставленням до культури і спорту. 1771 р. там уперше відкрився торговельно-розважальний заклад "Колізей", у якому відвідувачі могли зробити покупки в магазині, завітати у галерею, подивитися концерти, балети, бали-маскаради й спортивні змагання. У цьому прикладі навіть назва закладу - "Колізей" - наводить на очевидні історичні паралелі й більш ніж красномовні алюзії.

У Новий час провідні європейські країни, що пережили промислові революції, являли собою суспільства 3 яскраво проявленою соціальною мобільністю, індивідуалізмом та конкуренцією. Доба індустріалізації лібералізувала заняття фрізичною культурою і спортом, вони стають частиною масової культури. Якщо спортивні змагання періоду архаїки та середньовіччя мали зазвичай жорсткий і невгамовний характер, легко переходили у криваві сутички, то за тепер вони стали обмежуватися визначеними правилами та суддівством, спорт набуває рис професійної діяльності. Виникають спортивні клуби, агенції, ліги. В авангарді цього руху виступили представники середнього класу та національних еліт. 
Народні види спорту були витіснені на периферію процесів модернізації.

Разом із зародженням і розвитком буржуазії феодальний уклад життя сприймався чимраз більше як застиглий, негнучкий. Буржуазне суспільство бажало бути рішучим, готовим до стрімких змін, індивідуальної підприємницької ініціативи, а отже, людина мала стати сильною, спритною, рухливою. Уже у XVIII ст. дістали розвитку спеціальні фрізичні тренування, що спрямовувалися на покращення стану здоров'я та самовідчуття. Лінощі, пасивний спосіб життя, нездорове харчування, які відбивалися у вигляді аморфного тіла, цілеспрямовано висміюються як ознака відсталості, приналежності до маргінесу, що знаходиться обабіч соціального прогресу. У моду входить струнка й спортивна статура як ознака приналежності до провідних верств населення. Численні карикатури, бульварні романи піддають осміху уповільнений спосіб життя старої еліти. Але для розмаху соціокультурних зрушень цього виявилося недостатньо. Дух конкуренції в економіці підштовхнув фрранцузького аристократа барона П. де Кубертена до ідеї змагальності як ключової у спорті, позаяк економічна конкуренція та спортивна змагальність психологічно $є$ рівнозначними й однотипними. Людина, спантеличена швидкістю змін, розчарована в ідеалах релігійної моралі, шукала нові ціннісні орієнтири й отримала їх у вигляді олімпійської ідеї: "Citius, Altius, Fortius". Головним спортивним досягненням тепер стає рекорд, гонитва за яким налаштовує все життя на нескінченну боротьбу. Одночасно спорт перетворюється на один із трансляторів національної ідеї, через спорт пропагуються гасла національної солідарності та позначається конкуренція між державами.

Цитуючи М. Вебера, Т. Алкемейєр помічає: "Олімпійські ігри - це повторне зачарування сучасності: це сцена, на яку індустріальне суспільство виставило пануючі в ньому образні ідеали... Олімпійські ігри пов'язали романтичну тугу за єдністю, цілісністю й духовним смислом із сучасними утопіями безмежного вдосконалення тіла, коли змагання вважається рушієм прогресу" [22, с. 15-17]. Розмірковуючи над ідеєю відродження олімпізму як фрілософрії життя, Т. Алкемейєр звертає увагу на те, що додатковим фактором привабливості став його анахронізм: Кубертен "обдарував атлетів... вишуканим захопленням і харизмою, узятою з підручників історії" [22, с. 16]. За його задумом, завдяки святковості Олімпіад, піднесеному характеру спортивних дій, індивідуальній енергії, яка вивільнюється в людини під час змагань, цивілізація, що старіє, мала наповнюватися диханням мужності й молодості. У спортивній романтиці тих часів віддзеркалилися ідеї першості розуму, науки, прогресу, соціального оптимізму. Радість від фозичних зусиль трансформувалася в повагу до основних етичних принципів епохи. "Ода спорту" (1912) П. де Кубертена, у якій було узагальнене модерне уявлення про спорт, мала надихати й надихала до самовідданості та героїзму: "О спорт! Ти - насолода!... О спорт! Ти - зодчий!... О спорт! Ти - справедливість!... О спорт! Ти виклик!... О спорт! Ти - Благородство!... О спорт! Ти радість!... О спорт! Ти - плодотворність!... О спорт! Ти прогрес!... О спорт! Ти - мир!". У вірші оспівується "радість руху", "радість життя". "Спорт!... Як тільки ти посміхнешся, тільки-но підеш по країнах пружною радісною ходою, над землею розливається спокій...".

Проте рубіж XIX-XX ст. поклав початок черговому перехідному періоду, який, на думку більшості дослідників, триває досі. Цей перехід - затяжний і насичений визначними подіями - з другої половини $X X$ ст. увійшов у фразу поширення святково-карнавального світовідчут- тя. Переживши революції, тоталітарні режими (які, до речі, використовували піднесений і святковий дух спорту зі своєю ідеологічною метою), світові й локальні війни людство вступило в особливий режим існування. Передусім, це стосується західної цивілізації, яка з потраплянням у кризовий стан опинилася ще й у коловороті нескінченного свята.

Це пояснюється тим, що в секуляризованому суспільстві свято виступає як інструмент затримання процесу розпаду в умовах, коли розрив із попереднім ходом історії надзвичайно великий, а інтенсивні зміни загрожують ентропією. Свято - це особливий режим існування соціуму й культури в умовах переходу та кризи. Повернення в первісний хаос, розгул сміхової стихії, створення атмосфери святковості й карнавальності були підготовлені постмодерним світоглядом.

Постмодерн настав як час "після"-розуму, "після"прогресу, "після"-науки, "після"-самовідданості, "після"героїчності. Перехід від розуму до невір'я та іронічного скептицизму, усвідомлення, що людина - не центр Всесвіту, негативний досвід розбудови модерністських держав, який обернувся тоталітаризмом і війнами, далися взнаки. Розчарування в ідеалах розуму та прогресу призвело до самоствердження "суспільства вистави", "суспільства споживання", "інформаційного суспільства", "гумористичного суспільства" тощо. Ідеали споживання й гедонізму, що заступили ідеали розуму і прогресу, породили консюмеризм як практику отримання насолоди від накопичення речей, вражень тощо. Ідеологія косюмеризму виражається в такому гаслі: "Живи і радій тепер!". У ній немає висоти надприродного і глибини природного, у ній немає взагалі ніяких абсолютів, а тим більше історичної перспективи. Спорт як об'єкт споживання, спорт як шоу-бізнес живиться постмодерним відчуттям із його ковзанням по поверхні та збиранням фрагментарних пазлів у випадкові сюжети без смислу. Карнавалізований спорт стає різновидом ескапізму, способом утечі від реальності. Він наслідує окремі зовнішні форми свого попереднього існування, але значно деформує їх внутрішній зміст, спрощує, редукує до прийнятних форматів карнавалізованого суспільства.

Ознаками постмодерного спорту є його видовищність, медійність, розважальність, естетизація та зрощення з індустрією шоу-бізнесу. Історично злиття спорту та індустрії відбулося в Америці під час Великої депресії, коли люди припинили ходити на стадіони й сплачувати великі гроші за квитки на футбол, бейсбол або бокс. Якщо колись мільйонні прибутки давали можливість власникам команд безбідно жити, не замислюючись про рекламу, то під час депресії спорт, як і вся економіка США, опинився у важкій ситуації, у людей просто не було грошей, щоб оплачувати розваги. Повсюдно закривалися клуби, руйнувалися ліги. У цей момент виникли три ключові ідеї, які назавжди змінили спорт новітньої доби, перетворивши його на справжню індустрію: 1) спорт мав бути ще більш видовищним, тобто являти собою повномасштабне шоу; 2) спортивні змагання мали перевести з денних на вечірні години, щоб не тільки бездіяльні громадяни, але й ті, що працюють, могли ходити на матчі; 3) слід було, нарешті, організувати трансляції спортивних репортажів по радіо, адже раніше були сумніви, що вболівальники будуть сидіти в барах або вдома і не ходитимуть на стадіони. Перша ж трансляція по радіо спортивних змагань спростувала всі застороги, бо кількість зацікавлених спортом, навпаки, зростала в геометричній прогресії.

Поява телебачення посилила ситуацію. Більше того, формат телетрансляцій тепер диктував свої вимоги до спорту. Щоб опинитися "у телевізорі" різні види спорту 
сильно змінилися, підпорядкувавшись комерційній логіці телетрансляцій. Тривалість, дату й час змагань визначає телемовник; він же розміщає за графіком рекламу в ході трансляцій. "Спортивне знаряддя перетворилося на справжню іграшку" (Е. Фінк), але в руках телевізійників, а не спортсменів. Під впливом телебачення зменшувалося спортивне знаряддя, щоб воно мало вигідний вигляд у кадрі, або збільшувалося, як тенісний м'яч, який до того ж з білого було перефарбовано на жовтий, бо так його краще видно на екрані. Те саме відбулося із м'ячами для гри у футбол, волейбол, гандбол; увесь спортивний інвентар мав виглядати ошатно, яскраво, святково.

В ідеалі спортивні змагання мали бути динамічними й дуже простими. Усе, що треба задля їх прикрашення й урочистого антуражу, створюють за допомогою спецефектів під час телетрансляції. Інформаційне суспільство з його ІТ-технологіями виховало покоління людей з мозаїчним, кліповим типом свідомості, що відбилося на способах передачі спортивної інформації в постмодерному суспільстві. Усі додаткові супровідні дані подаються на екрані, що зближує спортивні трансляції з комп'ютерним геймерством: підсвітка, статистика, що постійно оновлюється. Так виникає віртуальна реальність спорту.

Сучасний спортивний стадіон по-своєму створює гіперреальність: на трибунах і арені у вільному доступі $\epsilon$ швидкісний вай-фай. Глядачі можуть онлайн отримувати інформацію про біографію гравців, розглядати їх фото у своїх смартфонах прямо під час змагань, стежити за статистикою матчів. Режисери матчів паралельно подають зображення емоційної реакції вболівальників на велике табло стадіону. Із цього приводу У. Еко пише: "У спорті вже не має значення гра тих, що грають..., а має значення карнавальна метушня перед змаганнями, за кулісами змагань, після змагань. Посправжньому грає не той, хто грає, а той, хто вдень і вночі з ранку понеділка до вечора неділі безупинно витріщається на тих, хто грає" [2, с. 146].

Приміром, американські споживачі, прийшовши на спортивний стадіон, усе більше часу спостерігають не перебіг ігри в реалі, а її трансляцію за допомогою смартфонів. За статистичними даними, американці витрачають мільярди доларів на мобільний спортивний контент, а під час змагань, навіть перебуваючи на стадіоні, 85 \% часу дивляться на монітор смартфона. Спорт через екрани телевізорів та монітори смартфонів виглядає більш яскраво й видовищно. Спеціальні програми дозволяють уболівальнику дивитись повтори найцікавіших моментів гри й не тільки у режисерській версії, але й замовляти "потрібну картинку" - цікавий для них кут зору з камер, що стоять по периметру спортивної арени. Людям уже не цікаво дивитися весь процес спортивного змагання цілком, вони хочуть тільки "смачненького" (на цьому побудовані численні гумористичні передачі про спорт, коли під музику подається нарізка кадрів із комічними й найбільш вражаючими фрагментами змагань). Безпосередньо перебуваючи на стадіоні, глядачі бачать не те, що відбувається справді, а створюють для себе штучну реальність. Завдяки новітнім IT-технологіям постмодерний спорт стає все більш віртуальним, фрагментарним і симулякризованим. Коли спортсмени на спортивному майданчику демонструють у змагальному запалі силу, стрімкість, спритність, створюють ігрову інтригу та тріумф перемоги, глядачі на трибунах не переймаються питаннями щодо ціни їхньої розваги (багаторічні тренування, травми, самозречення, самопожертви спортсменів), вони облаштовують "свято-для-себе".
Увесь спортивний ентертейнмент спрямований на споживання глядачами вражень, клубного одягу, рекламної продукції, їжі тощо. Скажімо, стадіон Madison Square Garden має 15 кафе та ресторанів тільки безпосередньо на своїй території, страви декількох десятків національних кухонь можна замовляти через смартфон, сплачувати карткою й отримувати прямо на своєму місці. Свято спорту для вболівальників - це можливість бачити лише те, що приносить задоволення, їсти й пити те, що подобається, виплескувати свої емоції, коли забажається, веселитися від отриманого задоволення і створювати через вітальний сміх особливу атмосферу гедоністичного надміру. Соціокультурний простір сьогодення - це середовище "нової архаїки". Діонісійське начало сучасної культури проявилося в постмодерному спорті, у якому домінує оргіастичне, тілесне, чуттєве, спонтанне. Діонісійське спрямування властиве людині на противагу аполлонічному з його гармонійністю, поміркованістю. Отже, зараз особлива увага приділяється природному, хаотичному, замість раціонального й упорядкованого. Можна сказати, що романтичні смисли, які закладалися П. де Кубертеном у його "Оді спорту", наразі вихолощені, позаяк рядки "О спорт! Ти - насолода!... О спорт! Ти - радість!... О спорт! Ти виклик!" і т. ін. наповнилися зовсім іншим змістом. Сьогодні найбільш адекватним щодо наявної ситуації є гасло: "О спорт, ти - карнавал!".

Карнавалізація спорту є відгуком на кризу в його розвитку. А. Гуттман про цей стан висловився так: "Цирк на похороні - не найточніша метафора, але що робити, якщо форма (Gestalt) сучасного спорту визначилася в гранично різкому контрасті із первісним, стародавнім, середньовічним спортом [17, с. 15]. Очевидно, що всі ознаки карнавалізації як соціокультурного феномену постмодерну притаманні й сучасному спорту. Карнавалізація повертає людину й суспільство у стан веселої відносності свята, картини якого мають символічне значення. Зміст цих образів можна усвідомити не стільки шляхом раціонального розуміння, скільки через естетичне "вчування" - занурення в карнавальну атмосферу, особливе світовідчуття та світосприйняття карнавалу як панування несвідомого. Провідником карнавальної атмосфери є сміх, завдяки якому відбувається "перегортання" смислів і знаків, виникають бінарні опозиції "священне-профанне", "високе-низьке", "великенице", "мудре-дурне" тощо, застосовуються сміхова антиповедінка, лайка, інвективи (М. Бахтін). У центрі карнавалізації - ідея про "інверсію подвійних протиставлень" тобто перегортання смислу бінарних опозицій: коли верх (раціональне, духовне) стає низом (матеріально-тілесним), коли міняються місцями чоловіче й жіноче (чоловіки надягають жіночі маски та навпаки), коли королем стає раб, блазень (увінчання-розвінчання), коли міняються ролями життя і смерть.

Перш за все привертає увагу карнавалізація образу спортсмена. 3 одного боку, на відміну від шоу-бізнесу та кіноіндустрії, у спорті із "нічого" не можна "зліпити" героя, з іншого боку, королі й королеви карнавалізованого спорту легко розвінчуються в рабів спортивної індустрії, бо на них одразу ж після "лаврових вінців" надягають торговельні ярлики. Про них так і говорять: "він/ вона вартує стільки-то". Коротку мить тріумфу в ролі "героя", і переможця знижують до статусу "товару", що асоціюється зі стародавнім визначенням раба, "як знаряддя праці, що говорить", речі, що має функціональне призначення. Навіть одна поразка розчаровує і гнівить уболівальників. Спортивні зірки постійно переживають карнавальний стан "увінчання-розвінчання". Спорт сьогодні - це світ шалених грошей, який зрощується з інши- 
ми сферами суспільства. У 1908 р. невдах олімпійських змагань утішали єпископи, в устах яких ще могло народитися гасло: "Головне - не перемога, головне участь". На початку XXI ст. місце головних мотиваторів у спорті зайняли менеджери, імпресаріо, спонсори, висунувши іншу формулу: "Якщо ти другий - тебе ніхто не знає". Спорт нині - заняття небезкорисливе. Уже наприкінці 80-х рp. XX ст. було стерто межу між аматорами та професіоналами в Олімпійському русі. У постмодерному спорті чемпіон - це не тільки той, хто виграє спортивні змагання, це той, хто здатен конвертувати щойно отриману перемогу в славу, автомобіль, престижну квартиру, рекламний контракт із фрірмою світового масштабу. Він має "пустити коріння" в музичному бізнесі, кіно або політиці.

Естетизація спорту перетворила спортсменів на бажаних гостей у будь-якому секторі індустрії розваг і видовищ. У класичному спорті акценти припадали на його етичні аспекти - захоплення силою волі атлетів, їх самодисципліною, здатністю підпорядкувати тіло духу, у постмодерному переважають конотації тілесності, чуттєвості, еротизму спортсменів, що цінуються не менше, аніж традиційні спортивні якості. У постмодерному спорті відбиваються суперечливі процеси: тіло не просто підпорядковується волі, а зводиться на п'єдестал та прославляється; одночасно у змаганнях випробовуються людські можливості, виявляється їхня межа, що призводить до "монстризації" образу спортсменів. "Що робити, якщо тепер більш за все затребувані видовища надлюдських можливостей та еротика зі спортивними аксесуарами" [17, с. 15-17].

Якщо за модерних часів "...атлети стали першими іконами мас, тому що несли в собі ідею безмежних можливостей людини й розвитку ... найкращих здібностей" [23, с. 324], то символом переходу до постмодерного спорту є культуристи і бодибілдери. Підкреслена сексуальність накачаних тіл зробила з них нові зразки для наслідування, у набутті опуклих форм з'явився додатковий смисл. Г. Маркузе зауважував: "Ерос наново переглядає концепт розуму: розумне те, що гарантує задоволення". Суміш спортивності та естетизму знайшла відгук у мільйонів послідовників бодибілдингу. Тренування в "качалці" стають повальною модою, оскільки під шкірою спортсмена-культуриста "перекочуються не просто мускули, а матеріалізована воля", при цьому "культуризм наближується парадоксально до мистецтва, балету, фігурного катання". Як зауважує В. Назіпов, Арнольд Шварценеґґер - це "дивний "символ краси й жаху", що "...найбільш усвідомив свою волю до влади", який "перемагає не тільки статурою і волею, але й насмішкою та натхненням" [24, с. 52-54]. Видатний Термінатор та герой дурнуватих комедій, непереможний Арні й 38-й губернатор штату Каліфорнія несе в собі риси героя-трикстера, що легко перемикаються "на вимогу". Секрет його успіху вбачається в його багатогранності, умінні являти публіці різні свої сторони. "Перетворення - ось джерело влади трикстера" (Е. Канетті) [25, с. 406].

Спортсмени минулих епох використовували тіло як знаряддя, як інструмент, завдяки якому можна було дотягнутися до трансцендентного, божественного, сьогодні атлетичне тіло - це засіб, за допомогою якого можна схопити за роги золоте теля, досягти успіху, визнання, популярності. У суспільстві масового споживання спостереження за тим, як на спортивному полі народжуються нові міліонери, зірки шоу-бізнесу, політики, перетворило спорт на розвагу й секуляризовану віру, об'єкт поклоніння одночасно. Елімінація решток власне релігійної свідомості призводить до появи нових ідолів. На цей фракт звертає увагу ряд дослідників. Наприклад, М. Сараф припускає "розуміння спорту в сучасному суспільстві (достатньо позбавленому поклоніння християнським символам) як аналогу, або ж замінника релігії" [26, с. 6]. Г. Горбунов продовжує цю думку: "Спорт створив новий культ зі своїми кумирами і служителями; він створив нові ритуали й обряди, нові масові дійства. Тут, на острові особливого життя, свої храми, гімни, символи, пости, одяг, відмова від багатьох світських задоволень. Моляться тут на спортивний результат - на Успіх" [27, с. 16].

Успішний спортсмен має бути переможцем у всіх своїх проявах. Б. Паскаль стверджував, що між двома способами справити враження: "способом переконання" і "способом зачарування" останній має перевагу. Саме тому цілі команди стилістів працюють над іміджем спортсмена, позаяк він має візуально опредмечувати свої вольові якості, демонструвати унікальну індивідуальність. Особа, що наділена чарівністю, приречена на людську увагу, спортсмен зобов'язаний випромінювати позитивний настрій, упевненість у власній непереможності. Відкритість, щира посмішка - це фрірмовий знак, емблема спортсмена, як і атрибутика спортивного клубу, за який він виступає. Стильний одяг, макіяж, уміння "світитися" доброзичливістю - це привід для потрапляння портретів спортивних героїв на обкладинки глянсових журналів, які приносять додаткові прибутки їхнім клубам. Згодом відбувається зворотна реакція: спочатку дехто зачаровується іміджом спортивної зірки, а вже потім іде на бокс, футбол, художню гімнастику, теніс, щоб подивитися на красеня чи красуню з обкладинки.

У цій гонитві за рекордом, за золотими медалями та всіма наслідками, що супроводжують спортивні перемоги, спортсмени все частіше відходять від розуміння спортивного способу життя як здорового. У. Еко неодноразово іронічно зауважував, що "здоров'я" лишається таким, допоки не перейдена риска, за якою можна померти "...від цих необхідних вправ, що дарують свободу; це як сміх Маргутта, який вибухає від надлишкового здоров'я", починається деградація самого принципу змагання. Атлет стає монстром, коли "...з'являється виводок людських істот, призначених для змагань. Атлет - істота з одним гіпертрофованим органом, його тіло перетворено на майданчик для безперервної гри та на її ексклюзивне джерело. Атлет - монстр, він - Людина, Котра Сміється, гейша з розчавленими й атрофованими ногами, предмет тотальної інструменталізації [28, с. 190]. Окрім того, спортивна гра стає "...настільки навантажувальною, що ії не виконаєш без наркотиків" [2, с. 146]. Уже не секрет, що в прагненні нових рекордів атлети вживають анаболіки та інші стимулятори. Різноманітні фармакологічні препарати допомагають їм перевершити самих себе й добитися найвищих результатів. Мораль постмодерну цього не забороняє, а навпаки, підтримує: "Гасло цілих десятиліть останніх часів: самореалізація через саморуйнування" (А. Гуттман)

"Трикстерські перетворення" у спорті торкнулися не тільки перегортання смислів "здоров'я"-"каліцтво", але й іншої пари карнавальних бінарних опозицій - "чоловіче"-"жіноче". Парадоксальний, іронічний, ігровий, імпровізаційний, евристичний характер постмодерної естетики відбився на спорті. Ми все частіше дивуємося "сучасному маскараду тілесного самоконструювання" (Т. Алкемейер) [22, с. 6-18], у якому втрачаються риси суто "чоловічого" чи "жіночого".

Поки теоретики дискутують з приводу "гендерної асиметрії" в спорті, що вона не на користь жінок (3. Гаса- 
нова) [29, с. 56-58], або називають жіночий атлетизм "логічним завершення жіночої емансипації" й "бездумною спробою прорватися до андрогінізму без чоловіка" (В. Хамітов) [24, с. 52-54], спортсмени обох статей перехресно опановують види спорту, котрі $\epsilon$ підкреслено маскулінними або фемінними. Особливо жінки проявляють зацікавленість такими зазвичай чоловічими видами спорту, як фрутбол, бокс, важка атлетика, східні єдиноборства. Але й у традиційних видах спорту жінки покращують свої спортивні досягнення та скорочують розрив результатів із чоловіками. Залучення жінок у спортивні дисципліни, що $є$ прерогативою чоловіків, часто вступає в протиріччя зі звичними критеріями жіночності. Якщо жінка бере участь у нетрадиційній фрізичній активності, вона набуває рис "чоловікоподібної", "нежіночної", "неприродної". Спортсменки високого класу навіть у таких видах спорту, як плавання, спортивна гімнастика, легка атлетика, переважно мають маскулінну зовнішність [30]. Це додає провокативності, видовищності спортивним змаганням: жінки з нерозвиненими грудьми, масивною м'язовою масою, жорсткими рисами обличчя мають вигляд маскарадних персонажів. У постмодерному спорті "велика опозиція (Чоловіче/Жіноче)" (Ж. Бодрійяр) розпочинає гру "хитрих машкар". Саме "гра з розумінням" (відсторонення, зіткнення полярних значень, інтересів, очікувань) створює інтригу змагань, викликає і стимулює сміх як реакцію на демонстрацію в спорті модифрікованої тілесності.

Уже під час Олімпійських ігор у Мехіко (1968 р.) уперше постало питання про необхідність секс-контролю та біологічного визначення жіночності спортсменок переважно з країн східного блоку, бо вони демонстрували надзвичайні можливості та постійно били світові й олімпійські рекорди. Той факт, що статева ідентичність спортсменок викликала сумнів й виникала необхідність визначати генетичну стать шляхом проходження хромосомного тестування, помітно підігрівала глядацьку увагу до спортивних подій. За три десятиріччя, поки діють правила фрізичної експертизи та хромосомного тестування, жодного чоловіка, що маскується під жінку, знайдено не було. Проте метаморфози в образі жінок, що змушують піддавати сумніву їх статеву приналежність за зовнішніми ознаками, відзначаються все частіше.

Карнавальна інверсія жіночого й чоловічого в спорті має вигляд здебільшого не жартівливо-ігрового маскування, вона свідчить про розширення спектра маніфестацій "жіночного" і "мужнього" та фрактично через їх широке різноманіття розмиває межі щодо статевої ідентифікації. Оскільки в постмодерному спорті досконале тіло - це еротичний об'єкт, глядачів цікавить сексуальна орієнтація спортсменів, особливо коли вона $€$ нетрадиційною. Гомосексуальність у спортивній спільноті все ще $\epsilon$ табуйованою темою, проте скандали виникають постійно. У великому спорті багато гомосексуальних спортсменів, що змушує спеціалістів говорити про їхню особливу психофрізіологію. Так, "геям-спортсменам приписують жіночі якості: емоційність, м'якість, легку вразливість, стервозність, гидливість - тобто стереотипно жіночі якості" [31]. Годі вже й говорити про Gay Games з їх такими екзотичними варіаціями, як фрігурне катання одностатевих пар, чоловіче синхронне плавання, яке завжди було "винятково жіночим видом спорту" й у якому тепер чоловіки змагаються у проявах жіночності, гнучкості, пластичності.

Уболівальники - це те, без чого не можна уявити спорту. Вони лише своєю присутністю на трибунах додають додаткових карнавальних фарб у спортивне ви- довище. Якщо для американських уболівальників надважливим $є$ технічний супровід змагань, європейці більш активно спостерігають за їх перебігом та жваво реагують на них. Проте їх усіх поєднує демонстрація перетікання символів життя в символи смерті й навпаки, що притаманно карнавальності. Дії фанатів на трибунах спортивних стадіонів не можна схарактеризувати інакше, як сміхову антиповедінку. Грим у кольорах улюбленої команди або прапора країни, чудернацькі перуки, комічні головні убори, навмисне оголення тіла - усе це супроводжується сміхом і руховою активністю: створенням "хвилі", розтягуванням величезних плакатів, танцями; гучними "кричалками", застосуванням забороненої піротехніки, фаєрів, бенгальських вогників, а також барабанів, дудок, тріскачок. Образливі вигуки на адресу супротивника і схвальні гасла для своєї команди $€$ життєствердними символами. Сприйняття вболівальниками програшу як смерті $є$ відлунням стародавніх ритуальних фрорм спорту, коли перемога означала прихильність богів та гарантію продовження життя, роду, а поразка - символічне умирання. Зважаючи на те, що в спорті завжди є політичні підтексти, боротьба набуває особливої гостроти. Отже, якщо для спортсменів спорт - це гра, то для відданих уболівальників це справжня битва за життя, а фанати команди-супротивника - це реальні вороги. Сутички між прибічниками різних команд часто називають "фанатськими війнами". Зіткнення на трибунах або поза їх межами є немов ілюстрацією розуміння духу карнавальності С. Аверинцевим. Він зазначав: "На початку начал усілякої "карнавалізації" - кров" [32 с. 13].

Дії фанатів іноді нагадують психічні атаки, це явище має назву "слем". "Слем", що в перекладі означає "шизня", - це хуліганська дія, яка $€$ аналогом карнавальних смертельних зіткнень різних фратрій. Головне гасло їх учасників: "Так, ми - ненормальні!". Одночасні підкидання в повітря клубних шапочок і шарфів, ритмічні рухи та гучні аплодисменти - це тільки для розігріву. Потім починаються скандування й вигуки з ненормативною лексикою, образи на адресу супротивників, скабрезності й дикунський регіт, що дуже рифмується з утробним гумором Рабле... Ну й фінальна фаза - криваві бійки як залицяння зі смертю з метою самоствердження. "Хто сильніший, той не тільки правий, але й просто - живий".

Просякнутий карнавальними смислами постмодерний спорт за законами жанру порушив кордони свого "хронотопу". Із завершенням матчів і оголошенням результатів змагань спортивне видовище виходить поза межі стадіонів. Карнавалізований спорт значно впливає на постмодерну повсякденність, вносить додаткові відтінки в її тотальну святковість. Постмодерне суспільство переживає тривалу спортивну лихоманку. Це проявляється в моді на спортивний одяг. Так, скажімо, започаткуванню популярного повсякденного стилю "casual" ("кежуел") посприяли футбольні франати Великої Британії. Зірки спорту також задають певні тренди, популяризують фешн-бренди. Через моду на молодість характеру епідемії набуває захоплення такими гедоністичними видами спорту, як фітнес, пілатес, аеробіка, бодибілдинг. Нове віяння - спортивна селфоманія. Інтернет заповнений селфі під час тренування: це світлини пересічних користувачів соціальних мереж та зірок шоу-бізнесу, кіноіндустрії, політиків у спортивних інтер'єрах. Утім, часто бажання "здаватися" спортивними випереджає потребу "бути" такими. Нерідко за результат своїх спортивних подвигів видають мистецтво пластичних хірургів, що моделюють зовнішність відпо- 
відно до стандартів атлетичної фрігури. Спортивне "тюнінговане тіло" має свою семантику - приналежність до забезпечених верств населення. Заняття у спортивних клубах під керівництвом професійних тренерів - це дозвільна практика, що потребує достатньо вільного часу й фінансових можливостей, позаяк $\epsilon$ недешевим задоволенням. Бути струнким, підтягненим, спортивним значить відчувати себе "своїм" на цьому святі життя. Проте мати спортивний вигляд замало, треба ще приймати "спортивний сенс життя". Х. Ортега-і-Гассет пояснює це поняття як добровільне прийняття виклику напруження життя, яке за допомогою творчої активності необхідно перебудувати [4, с. 139-145]. У цьому сенсі людина може виглядати так, як їй заманеться, але своє життя сприймати на кшталт спортивного змагання.

Окрема тема - спорт і національна ідентичність. Як відзначає Т. Еденсор, "...через спортивні свята, карнавали, народні гуляння, які іноді супроводжують офіційні свята та церемонії, національна ідентичність отримує тілесне вираження та емоційну експресію. Спорт $є$ одним із найяскравіших і найпопулярніших національних перфомансів. Спорт, унесений в матрицю національної ідентичності, дозволяє транслювати локальні події в події внутрішньонаціонального й навіть глобального масштабу. До того ж саме спорт дозволяє виразити національну ідентичність на глобальному рівні" [33, с. 74] наприклад, голландців уважають найпристраснішими вболівальниками у світі. Коли Голландія приймала в себе фрутбольне Євро-2000, нація начебто збожеволіла у святковій колотнечі. Уся країна одягнулася з голови до п'ят у символічні кольори. Від столиці до маленьких містечок - усі об'єкти були зафарбовані в колір національної збірної. Помаранчевими стали споруди - від приватних до офіційних, а також тротуари, авто, собаки, кішки, велика рогата худоба, навіть трава на газонах і вода у фонтанах.

Постмодерний спорт приваблює як високе мистецтво, так і шоу-бізнес, поєднує непоєднуване. Напрочуд неочікуваним для вболівальників виявився дует Фредді Мерк'юрі та Монсеррат Кабальє на відкритті Олімпіади в Барселоні 1992 р. Злиття шоу-бізнесу й спорту проглядається навіть в утворенні зіркових сімейних пар, які постійно створюють "інформаційні приводи" про своє позаспортивне та позамистецьке життя.

Отже, постмодерний спорт, позначений головними "мітками" карнавалізації, являє собою завершений і цілком сформований феномен сучасного соціокультурного простору. П. Бурдьє, аналізуючи історію становлення спорту, дійшов висновку, що вона є "відносно автономною історією", яка має "свій час, свої закони розвитку, свої кризи, ... особливу хронологію" [18, с. 339-360]. Постмодерний спорт також явище історичне й перехідне, як і античний атлетизм, і середньовічні лицарські турніри. Карнавалізація спорту як відповідь на його внутрішню кризу та загальну кризову карнавальність соціокультурного простору має вивести людство на якісь нові рубежі. Сьогодні вже постає питання: "А що далі?". Дехто стверджує, що сучасний спорт із його "біомедичними технологіями, кібернетизацією тіла, реконструкцією філософських визначень рівності, гендерними дослідженнями тощо" (В. Нішуков) сягнув краю, межі свого розвитку. Надалі йдеться вже про реалії постспорту: кіберспорту, ЛГБТ-спорту, інтелектуальних ігор, етноспорту як реконструкції традиційних народних розваг тощо, які все ще вписуються в постмодерну парадигму, але задають інший вектор розвитку самого спорту. Названі види змагань зближують спорт із поп-артом: виникає можливість відійти від суворих правил та додати імпровізаційних моментів, дати волю випадковостям, розсунути межі спортивної спеціалізації, що розкриє нові ресурси для самовираження та саморепрезентації особистості через спортивні практики. Згортання карнавалізації спорту можливе за умови виникнення його оновлених форм.

Однак $є$ й прихильники збереження традиційного спорту, особливо його гуманістичної складової, - рівного доступу широких мас до безпосередніх фізичних занять, замість поширеного зараз пасивного споглядання за спортивними змаганнями інших. На думку У. Еко, "...якщо спорт (яким займаються) - це здоров'я, подібно до прийняття їжі, то спорт, на який дивляться, це інструмент з витягування здоров'я" [28, с. 190]. Неможливо обійти увагою критику постмодерного спорту марксистами (Д. Скот, Г. Едварс) та неомарксистами (Б. Рігауер, Г. Віннай, Ж. М. Бром). Якщо перші висловлювали фундаментальний сумнів щодо західного спорту, то другі розширили критичну позицію до всебічного неприйняття не тільки "збоченого капіталістичного спорту", але й самої ідеї спорту як соціального інституту. Неомарксистська радикальна позиція бере початок від ідей К. Маркса, 3. Фрейда та більш стриманих в оцінках майбуття спорту лідерів довоєнного неомарксизму (Т. Адорно, М. Горкгаймера, Г. Маркузе). 3 усіх ознак постмодерного спорту вони визнають лише секулярність і рівність. Весь викривальний пафос неомарксистів зводиться до виявлення ще декількох "смислових перегортань" у постмодерному спорті: "креативність-нормативність", "дозвілля-праця", "гра-експлуатація". Основні удари їхньої критики припадають на відсутність творчої спонтанності в надмірно регламентованому підході до змагань, перетворення гравців на суб'єктів виробництва, заміну живої гри фрактичною експлуатацією спортсменів, фрустрацію й провали в останніх як наслідки гонитви за рекордом, намагання через спорт "зберегти репресивну владу капіталістичного класу" тощо. Неомарксисти знаходять приховані функції постмодерного спорту в сексуальній сублімації через агресію, що, на їхню думку, покликано стримувати політичні революції проти капіталізму. Спорт - це не втеча зі світу праці, але, радше чітко структурована й функціональна копія цього світу. Звідси висновки неомарксистів: суспільству потрібна гра, а не спорт, бо "спорт репресує, а гра емансипує". Таким чином, у майбутньому, яке вони пов'язують $з$ настанням комунізму, спорт зникне, а гра займе його місце. 3 критикою постмодерного спорту виступають і представники східної цивілізації. Зокрема, колишній лідер Лівії Муаммар Каддафрі, який за життя зажив слави ексцентрика й сюрреаліста, а в міжнародній політиці здобув суперечливий статус "диктатора-блазня", у своєму "Заповіті" розмірковував про долю спорту, звісно, зі своїх ідеологічних позицій. Він не настільки радикальний, як неомарксисти, і його роздуми де в чому не позбавлені здорового глузду: "Тисячі глядачів, тих, що аплодують і сміються, які заповнюють трибуни стадіонів, - це тисячі уведених в оману людей, котрі, не маючи можливості займатися спортом особисто, бездіяльно сидять на трибунах і вітають чемпіонів, які перехопили в них ініціативу, відтіснили їх і монополізували спорт, використовуючи у своїх інтересах можливості, надані масам". Отже, спорт матиме сенс лише тоді, коли люди з трибун, згадавши або відчувши наново, які відчуття дарує цей вид фізичної активності, "поспішать на спортивні арени й почнуть займатися спортом, виступаючи в якості учасників, а не глядачів" [34, с. 200-221]. 


\section{Висновки}

Сучасний стан карнавалізації спорту є закономірним результатом його попереднього розвитку. Історично склалося так, що сміх як біосоціокультурний феномен і заняття спортом $€$ неодмінними супутниками одне одного. Сміх як феномен біологічний має витоки у нашій родовій пам'яті, це "вроджений та несвідомий, метакомунікативний сигнал... особливої негативістської гри", "антагоніст культури", "ії тимчасовий блокатор" (А. Козінцев) [35, с. 127-132], а як феномен культурний і соціальний він $€$ доконечною складовою, через яку проявляється їхній незавершений характер, потреба їх переростання в інші стани і якості, нові способи буття.

За часів дикунства сміх позначав перші проблиски усвідомлення людиною власних фрізичних можливостей. В античності сміх став обов'язковим атрибутом ритуальних спортивних змагань, забезпечував екстатичний зв'язок із надприродним, гарантував космічну й соціальну рівновагу. В умовах середньовічних двох світів сакрального та профанного лицарські турніри, що самі по собі були неабиякими видовищами, ставши частиною свята-карнавалу, дозволяли людям за допомогою сміху трансгресувати "туди"-"сюди"-"зворотно", шукаючи рівноваги між природним началом і суворими релігійними настановами, жорсткою соціальною ієрархією. Середньовічний спорт, уписаний у фрормат свята-карнавалу, давав людині нагоду жити одночасно у двох світах. Спорт Нового часу завдяки сміху дистанціювався від його попередніх історичних форм, секуляризувався й використав його в утилітарних цілях комерціалізації, профресіоналізації, масовізації тощо. Відтворення Олімпійського руху П. де Кубертеном було спробою повернути спорту дух свята, радості, натхнення від занять фізичною культурою, але вже на ціннісних засадах індустріального суспільства.

Отже, сміх у його різноманітних функціях, проявах, модифікаціях $€$ як невід'ємною складовою, атрибутом спортивного життя, так і незалежним агентом соціальних зрушень, завдяки якому встановлюються або скасовуються суспільні цінності та ідеали, створюється особлива святкова атмосфера як маркер "границі", "межі", "переходу" соціуму в цілому та спорту як соціального інституту в новий режим існування. Сміх із його амбівалентними можливостями включений у соціокультурну тканину як внутрішній рушійний механізм змін. Сміх діє і як "перемикач" смислів і цінностей, і як позначка в соціальній ритміці критичних станів суспільства, коли почуття, емоція, несвідоме бере гору над раціонально встановленим порядком, коли діонісійське начало культури перемагає аполлонічне. Завдяки сміху соціокультурний простір входить в особливий стан неспинного "діалогу-протиставлення" (Ю. Лотман) одних способів свого буття з іншими, альтернативними. У кризові періоди сміх блокує будь-які усталені норми, правила, що стримують подальший розвиток, і запускає в дію "аксіологічну дифузію", яка згодом забезпечує народження нових смислів буття, нових "ідеальних форорм".

За новітніх часів сміхова стихія карнавалізованого спорту змішала ідеологію постмодерну та семіотику карнавалу. Карнавалізоване соціокультурне середовище помітно вплинуло на спортивне життя, а постмодерний спорт, своєю чергою, додав святковості постмодерній повсякденності. Святковість, певна хаотизація теперішнього спорту $є$ ознакою його переходу в якийсь новий стан. Панування міфологічного світосприйняття, нова архаїка наводять на думки про сучасне прочитання аграрного культу - щоб "поховане" в землю зерно дало плід, воно має символічно померти. Отже, символічне повернення карнавалізованого спорту до хаосу, де панує сміхова стихія й відбувається "бродіння цінностей і ідеалів", $є$ необхідною умовою нового "творення", появи його нових історичних форм. Перспективи розвитку постмодерного спорту, стратегії збереження класичного спорту та його гуманістичних смислів, аналіз феномену постспорту тощо розкривають обрії подальших наукових досліджень.

\section{ЛПТРАТУРА}

1. Мосс М. Техники тела / М. Мосс // Общества, обмен, личность. - М. : Наука; Главная редакция восточной лит-ры, 1996. - С. $242-263$.

2. Эко У. От игры к карнавалу / У. Эко // Полный назад! "Горячие войны" и популизм в СМИ ; [пер. с итал. Е. Костюкович]. - М. : Эксмо, 2007. - 592 с.

3. Пономарчук В. А. Спорт как социальный институт / В. А. Пономарчук // Спортивная энциклопедия систем жизнеобеспечения / [ред. А. Д. Жуков]. - Изд. Юнеско, 2011. - 324 с.

4. Ортега-и-Гассет Х. О спортивно-праздничном чувстве жизни / Х. Ортега-и-Гассет // Философские науки. - 1991. № 12. - С. 137-152.

5. Хейзинга Й. Homo ludens / Й. Хейзинга. - М. : Мысль, 2001. - 346 c.

6. Diem C. Weltgeschichte des Sports / C. Diem. - 3 rd ed. 2 vols. - Stuttgart : Cotta, 1971.

7. Ібрагімов М. Філософрія спорту в генезі історико-культурологічних студій та у вітчизняних перспективах / М. Ібрагімов // Філософьська думка. - 2014. - № 1. - С. 97-110.

8. Лосев А. История античной эстетики / А. Лосев. - Т. VIII : Итоги тысячелетнего развития. Кн. 2. - М. : Искусство, 1994.

9. Косяк В. А. Эпистемология человеческой телесности / В. А. Косяк. - Сумы : ИТД "Универсальная книга", 2002. $140 \mathrm{C}$.

10. Frayssinet P. Le Sport parmi les beaux-arts / P. Frayssinet. - Paris : Arts et Voyages, 1968.

11. Иванов Вяч. Дионис и прадионисийство / Вяч. Иванов. - СПБ. : Алетейя, 1994. - 350 с.

12. Мосс М. Очерк о природе и функции жертвоприношения / М. Мосс // Социальные фрункции священного / [пер. с фр. под. ред. И. В. Утехина]. - СПб. : Евразия, 2000. - 448 с.

13. Пономарев М. Социальные функции ффизической культуры и спорта / М. Пономарев. - М. : Физкультура и спорт, 1974. - $310 \mathrm{c}$.

14. Lindsay Peter L. Attitudes towards Physical Exercise Reflected in the Literature of Ancient Rome, History of Sport and Physical Education to 1900 / Lindsay Peter L. ; [ed. Earle F. Zeigler]. - Champaign, Illinois : Stipes, 1973.

15. Ницше Ф. К генеалогии морали. Полемическое сочинение // Ф. Ницше. Соч. в 2-х томах / Ф. Ницше. - М. : Мысль, 1990. - T. II. - C. 407-524.

16. Элиас Н. О процессе цивилизации. Социогенетические и психогенетические исследования / Н. Элиас. - М. ; СПб. : Университетская книга, 2001. - Т. І: Изменения в поведении высшего слоя мирян в странах Запада; [пер. с нем.]. - 332 с.

17. Guttmann A. From Ritual to Record: The Nature of Modern Sports / A. Guttmann. - New York : Columbia University Press, 1978. - P. $15-55$

18. Bourdieu P. How Can One be a Sports Fan? / P. Bourdieu // During S. (ed.) Cultural Studies: A Reader. - London and New York : Routledge, 1993. - P. 339-360.

19. Дружинина Е. С. Структурообразующие элементы архетипа (на примере архетипов героя и Дон Кихота) / Е. С. Дружинина // Культура народов Причерноморья. - 2012. - № 231. - С. $112-116$

20. Яковенко И. Культура как система / И. Яковенко, А. Пелипенко. - М. : Языки русской культуры, 1998. - 396 с. 
21. Берк П. Популярна культура в ранньомодерній Європі / П. Берк ; [пер. з англ.]. - К. : УЦКД, 2001. - 376 с.

22. Alkemeyer T. Aufrecht und biegsam. Eine politische Geschichte des Korperkults / T. Alkemeyer // Bundeszentrale für politische Bildung (Hg.): Aus Politik und Zeitgeschichte. - APuZ 18 / 2007. - S. 6-18.

23. Sarasin P. Reizbare Maschinen. Eine Geschichte des Körpers 1765-1914 / P. Sarasin. - Frankfurt ; M. : Suhrkamp, 2001.

24. Хамитов В. Н. Философия одиночества. Опыт вживания в проблему. Одиночество женское и мужское / В. Н. Хамитов. - К. : Наук. думка, 1995.- 75 с.

25. Канетти Э. Масса и власть / Э. Канетти ; [пер. с нем. и предисл. Л. Ионина]. - М. : Ad Marginem, 1997. - 527 с.

26. Сараф М. Я. Спорт в системе культуры / М. Я. Сарафр. - Голицыно, 1994. - 72 с.

27. Горбунов Г. Д. Психология и спорт / Г. Д. Горбунов // Теория и практика физической культуры. - 1996. - № 12. C. $15-18$.

28. Эко У. Болтовня о спорте / У. Эко // Логос. - 2009. № 6 (78). - С. 188-193.
29. Гасанова 3. А. Женщины в изначально мужских видах спорта / 3. А. Гасанова // Теория и практика физической культуры. - 1998. - № 2 - С. 56-58.

30. Канатьев К. Н. Влияние гендерных особенностей спортсменов на психологический климат общения в спортивной команде [Електронний ресурс] / К. Н. Канатьев // Современные проблемы науки и образования. - 2015. - № 4. - Режим доступу : http//www/science-education.ru/article/view?d=20644.

31. Ильин Е. П. Дифференциальная психофизиология мужчин и женщин / Е. П. Ильин. - СПб. : Питер, 2002. - 544 с.

32. Аверинцев С. С. Бахтин, смех, христианская культура / С. С. Аверинцев // М. М. Бахтин как філософ / [ред. Л. А. Гоготишвили, П. С. Гуревич]. - М. : Наука, 1992. - С. 7-19.

33. Edensor T. National Identity. Popular Culture and Everyday Life / T. Edensor. - New-York; Oxford, England : Berg, 2002. DOI: $10.5040 / 9781474215305$.

34. Каддафи Муаммар. Завещание / Муаммар Каддафи. М. : Алгоритм, 2012 - 338 с.

35. Козинцев А. Г. Человек и смех / А. Г. Козинцев. - СПб. : Алетейя, 2007.- 236 с.

\section{Мальцева Ольга,}

кандидат философских наук, дочент кафедры социологии и сочииальной работьл,

Приазовский государственный технический университет, г. Мариуполь

\section{ФЕНОМЕН КАРНАВАЛИЗАЦИИ СПОРТА В ПОСТМОДЕРНОМ ОБЩЕСТВЕ}

В статье исследуется феномен карнавализации спорта в постмодерном обществе, выявляются причины, предпосылки, последствия постмодерной трансформации спорта как социального института, превращение его в коммерциализированное зрелище, индустрию, шоу-бизнес, развлекательную досуговую практику. Прослежено взаимное проникновение смеховой стихии в спорт и спорта в карнавализированное социокультурное пространство. Показано, что смех в его разнообразных функциях, проявлениях, модификациях является как неотъемлемой составляющей спортивной жизни, так и независимым агентом социальных изменений, благодаря которому устанавливаются или отменяются общественные ценности и идеалы, создается особенная праздничная атмосфера как маркер "границы", "перехода" социума в целом и спорта как его социального института в новый режим существования.

Ключевые слова: смех; спорт; карнавализация спорта; постмодерный спорт; социальные функции смеха.

\section{Maltseva Olga,}

candidate of philosophical sciences,

associate professor of the Academic Department of Sociology and Social Work, Pryazovskyi State Technical University, Mariupol

\section{THE PHENOMENON OF THE CARNIVALIZATION OF SPORT IN POSTMODERN SOCIETY}

This article examines the phenomenon of sport carnavalization in postmodern society, the reasons, preconditions, consequences of the postmodern transformation of sport as a social institution, turning it into a commercialized spectacle, industry, show business, entertainment practice. Traced the mutual penetration of the humorous elements in the sports and sports in karneval sfere in socio-cultural space. Thus, laughter in its various functions, manifestations, modifications is an integral part, an attribute of sport life, and an independent agent of social shifts, through which social values and ideals are established or abolished, a special festive atmosphere is created as a marker of the "boundary", the "border", "The transition" of society as a whole and sport as a social institution into a new mode of existence.

Keywords: laughter; sport; carnivalization of sport; postmodern sport; social functions of laughter.

\section{REFERENCES}

1. Moss, M. (1996), Body Techniques, Society, Exchange, Personality, Nauka, Moscow, pp. 242-263 (rus).

2. Eco, U. (2007), From the game to the carnival, Full back! «Hot wars» and populism in the media, Eksmo, Moscow, p. 592 (rus).

3. Ponomarchuk, V. (2011), Sport as a social institution, Sports encyclopedia of life support systems, AD-Ed. Unesco, p. 324 (rus).

4. Ortega y Gasset, Jose (1991), About the sports-festive feeling of life, Philosophical sciences, No. 12, pp. 137-152 (rus).

5. Huizinga J. (2001), Homo ludens, Mysl, Moscow, p. 346 (rus)

6. Diem, C. (1991), Weltgeschichte des Sports, 3 rd. ed., 2 vols, Cotta, Stuttgart (ger.). 
7. Ibragimov M. (2014), Philosophy of sport in the genesis of historical and cultural studies and in domestic perspectives, Philosophical thought, No. 1, pp. 97-110 (ukr.).

8. Losev A. (1994), History of Ancient Estetics, Vol. VIII: Results of Thousand-Than Development, Book. 2, Iskusstvo, Moscow (rus.).

9. Kosyak, V. (2002), Epistemology of human corporeality, ITD «Universalnaya kniga», Sumy, p. 140 (rus.).

10. Frayssinet P. (1968), Le Sport parmi les beaux-arts, Arts et Voyages, Paris, p. 27 (fr.).

11. Ivanov V. (1994), Dionysus and priodionism, Aleteyya, Saint Petersburg, p. 350 (rus.).

12. Moss M. (2000), Essay on the nature and function of sacrifice, Social functions of the sacred, Evraziya, Saint Petersburg, p. 448 (rus.).

13. Citation for: Ponomariev M. (1974), Social functions of physical culture and sports, Fizkultura I sport, Moscow, p. 310 (rus.).

14. Lindsay, Peter L. (1973), Attitudes towards Physical Exercise Refl ected in the Literature of Ancient Rome, History of Sport and Physical Education to 1900, ed. Earle F. Zeigler, Champaign, Stipes, Illinois, p. 179 (engl).

15. Nietzsche F. (1990), To the genealogy of morality. Polemic composition, 2 volum, Myisl, Moscow, p. 829, pp. 407-524 (rus.).

16. Elias N. (2001), About the process of civilization. Sociogenetic and psychogenetic studies, Vol. l: Changes in the Behavior of the Senior Layers in the Countries of the West, Universitetscaya kniga, Moscow; Saint Petersburg, pp. 332 (rus.).

17. Guttmann A. (1978), From Ritual to Record: The Nature of Modern Sports, Columbia University Press, New York, pp. 15-55 (engl).

18. Bourdieu P. (1993), How Can One be a Sports Fan? In: During, S. (ed.) Cultural Studies: A Reader, Routledge, London and New York, pp. 339-360 (engl).

19. Druzhinina E. (2012), Structural elements of the archetype (on the example of the hero and Don Quixote archetypes), Culture of the peoples of the Black Sea region, No. 231, pp. 112-116 (rus.).

20. Yakovenko I., Pelipenko A. (1998), Culture as a system, Yazyiki russkoy kulturyi, Moscow, p. 396 (rus.).

21. Burke P. (2001), Popular culture in the early modern era, UTSKD, Kyiv, p. 376 (rus.).

22. Alkemeyer T. (2007), Aufrecht und biegsam. Eine politische Geschichte des Korperkults, In: Bundeszentrale fur politische Bildung (Hg.): Aus Politik und Zeitgeschichte, APuZ, 18, pp. 6-18. (ger.).

23. Sarasin P. (2001), Reizbare Maschinen, Frankfurt / M., p. 324 (ger.).

24. Khamitov V. (1995), Philosophy of loneliness. Experience of living in a problem. Loneliness of women and men, Naukova dumka, Kiev, p. 75 (rus.).

25. Canetti E. (1997), Mass and power, Ad Marginem, Moscow, p. 527 (rus.)

26. Saraf M. (1994), Sport in the system of culture, Golitsyno, p. 72 (rus.).

27. Gorbunov G. (1996), Psychology and Sport, Theory and Practice of Physical Culture, No. 12, pp. 15-18 (rus.).

28. Eco. U. (2009), Chatter about sports, Logos, № 6 (78), pp. 188-193 (rus.).

29. Hasanova Z. (1998), Women in initially male sports, Theory and practice of physical culture, № 2, pp. 56-58 (rus.).

30. Kanatiev K. (2015), Influence of gender characteristics of athletes on the psychological climate of communication in a sports team, Modern problems of science and education, № 4, available at: http//www/science-education.ru/article/view?d=20644 (rus.).

31. Il'in, E. (2002), Differential psychophysiology of men and women, Piter, Saint Petersburg, p. 544 (rus.).

32. Averintsev S. (1992), Bakhtin, Laughter, Christian, M. M. Bakhtin as a Philosopher, Nauka, Moscow, pp. 7-19 (rus.).

33. Edensor T. (2012), National Identity. Popular Culture and Everyday Life, New York; Oxford, England: Berg (engl).

34. Gaddafi M. (2012), Testament, Algorithm, Moscow, p. 338 (rus.).

35. Kozintsev A. (2007), Man and laughter, Aleteyya, Saint Petersburg, p. 236 (rus.).

(c) Мальцева Ольга

Надійшла до редакції 07.12.2017 